\title{
Alum Treatment of Stormwater: the First Ten Years
}

Harvey H. Harper, Jeffrey L. Herr and Eric H. Livingston

Since at least Roman times, salts of aluminum have been added to drinking water and surface water to reduce turbidity and improve appearance. Aluminum sulfate, $\mathrm{Al}_{2}\left(\mathrm{SO}_{4}\right)_{3}$, commonly called alum, has been used extensively as a flocculating agent in the treatment of wastewater for over 100 years. In 1970, Jernelov was apparently the first to use alum to remove phosphorus from the water column of a lake in a whole-lake alum application conducted as part of a lake restoration project on Lake Langsjon in Sweden. The first U.S. lake to be treated with a whole-lake alum application was Horseshoe Lake in Wisconsin which received a surface application of $2.6 \mathrm{mg} \mathrm{Al} /$ liter in May 1970. Twelve years later, phosphorus concentrations were still below the pre-treatment level (Garrison and Knauer, 1984).

The addition of alum to water results in the production of chemical precipitates which remove pollutants by two primary mechanisms. Removal of suspended solids, algae, phosphorus, heavy metals and bacteria occurs primarily by enmeshment and adsorption onto aluminum hydroxide precipitate according to the following net reaction:

$$
\mathrm{Al}^{+3}+6 \mathrm{H}_{2} \mathrm{O} \rightarrow \mathrm{Al}(\mathrm{OH})_{3(\mathrm{~s})}+3 \mathrm{H}_{3} \mathrm{O}^{+}
$$

\footnotetext{
Harper, H.H., J.L. Herr and E. Livingstone. 1999. "Alum Treatment of Stormwater: the First Ten Years." Journal of Water Management Modeling R204-09. doi: 10.14796/JWMM.R204-09.

C CHI 1999 www.chijournal.org ISSN: 2292-6062 (Formerly in New Applications in Modeling Urban Water Systems. ISBN: 0-9697422-9-0)
} 
Removal of additional dissolved phosphorus occurs as a result of direct formation of $\mathrm{AlPO}_{4}$ by:

$$
\mathrm{Al}^{+3}+\mathrm{HnPO}_{4}^{\mathrm{n}-3} \rightarrow \mathrm{AlPO}_{4(\mathrm{~s})}+\mathrm{nH}^{+}
$$

The aluminum hydroxide precipitate, $\mathrm{Al}(\mathrm{OH})_{3}$, is a gelatinous floc which attracts and adsorbs colloidal particles onto the growing floc, thus clarifying the water. Phosphorus removal or entrapment can occur by several mechanisms, depending on the solution $\mathrm{pH}$. Inorganic phosphorus is also effectively removed by adsorption to the $\mathrm{Al}(\mathrm{OH})_{3}$ floc. Removal of particulate phosphorus is most effective in the $\mathrm{pH}$ range of 6-8 where maximum floc occurs (Cooke and Kennedy, 1981). At higher $\mathrm{pH}$ values, $\mathrm{OH}^{-}$begins to compete with phosphate ions for aluminum ions, and aluminum hydroxide-phosphate complexes begin to form. At lower $\mathrm{pH}$ values and higher inorganic phosphorus concentrations, the formation of aluminum phosphate $\left(\mathrm{AlPO}_{4}\right)$ is favored.

In 1985, a lake restoration project was initiated at Lake Ella, a shallow, 13.3 acre (5.4 ha) hypereutrophic lake in Tallahassee, Florida, which receives untreated stormwater runoff from approximately 163 acres (66 ha) of highly impervious urban watershed areas. Initially, conventional stormwater treatment technologies, such as retention basins, exfiltration trenches and filter systems, were considered for reducing available stormwater loadings to Lake Ella in an effort to improve water quality within the lake. Since there was no available land surrounding Lake Ella that could be used for construction of traditional stormwater management facilities, and the cost of purchasing homes and businesses to acquire land for construction of these facilities was cost-prohibitive, alternate stormwater treatment methods were considered.

Chemical treatment of stormwater runoff was evaluated using various chemical coagulants, including alum, ferric salts and polymers. Alum consistently provided the highest removal efficiencies and produced the most stable end product. In view of successful jar test results on runoff samples collected from the Lake Ella watershed, the design of a prototype alum injection stormwater system was completed. Construction of the Lake Ella alum stormwater treatment system was completed in January 1987, resulting in a rapid and significant improvement in water quality.

The alum precipitate formed during coagulation of stormwater can be allowed to settle in receiving waterbodies or collected in small settling basins. Floc settling rates vary considerably, depending on the chemical characteristics of the stormwater, typically ranging from $250-3000 \mathrm{~mm} / \mathrm{hour}$. Alum precipitates are exceptionally stable in sediments and will not redissolve due to changes in redox potential or $\mathrm{pH}$ under conditions normally found in surface waterbodies. Over time, the freshly precipitated floc ages into even more stable complexes, eventually forming gibsite. The solubility of dissolved aluminum in the treated water is regulated entirely by chemical equilibrium. As long as the $\mathrm{pH}$ of the 
treated water is maintained within the range of 5.5-7.5, dissolved aluminum concentrations will be minimal. In many instances, the concentration of dissolved aluminum in the treated water will be less than the concentration in the raw untreated water due to adjustment of $\mathrm{pH}$ into the range of minimum solubility.

There are currently 23 alum stormwater treatment systems either operational or under construction in Florida and one experimental system in Seattle, Washington. Alum treatment of stormwater runoff has now been used as a viable stormwater treatment alternative in urban areas for over ten years. Over that time, a large amount of information has been collected related to optimum system configuration, water chemistry, sediment accumulation and stability, benthic impacts, construction and operation costs, comparisons with other stormwater management techniques, and floc collection and disposal. A summary of current knowledge in these areas is given in the following sections.

\subsection{Initial Testing and Evaluation}

Once alum has been identified as an option in a stormwater retrofit project, extensive laboratory testing must be performed to verify the feasibility of alum treatment and to establish process design parameters. The feasibility of alum treatment for a particular stormwater stream is typically evaluated in a series of laboratory jar tests conducted on representative runoff samples collected from the project watershed area. This extensive laboratory testing is an essential part of the evaluation process necessary to determine design, maintenance, and operational parameters such as the optimum coagulant dose required to achieve the desired water quality goals, chemical pumping rates and pump sizes, the need for additional chemicals to buffer receiving water $\mathrm{pH}$, post-treatment water quality characteristics, floc formation and settling characteristics, floc accumulation, annual chemical costs and storage requirements, ecological effects, and maintenance procedures. In addition to determining the optimum coagulant dose, jar tests can also be used to determine floc strength and stability, required mixing intensity and duration, and determine design criteria for settling basins.

Since 1986, literally hundreds of laboratory flocculation jar tests have been performed to evaluate the effectiveness of alum for reducing concentrations of common constituents in stormwater runoff collected from a wide range of urban land use activities. A summary of mean removal efficiencies achieved during alum treatment of stormwater runoff for typical stormwater pollutants, based on testing performed from 1986 to 1996, is given in Table 9.1. Removal efficiencies are summarized for alum treatment of stormwater runoff at doses of 5,7.5 and 10 $\mathrm{mg} \mathrm{Al} /$ liter, as well as stormwater samples which were allowed to settle under quiescent conditions for a period of 24 hours to simulate removal efficiencies which would be achieved using a wet detention stormwater treatment basin for comparison purposes. 
As seen in Table 9.1, alum treatment of stormwater runoff consistently achieves an $85-95 \%$ reduction in total phosphorus, $65-75 \%$ reduction in total nitrogen, 95-99\% reduction in turbidity and total suspended solids (TSS), and 96$99 \%$ reduction in fecal coliform bacteria. Removal efficiencies of $50-90 \%$ are also achieved for heavy metals. The minimum tested dose of $5 \mathrm{mg} \mathrm{Al} / \mathrm{liter}$ is generally considered to be the minimum dose necessary to achieve acceptable floc settling characteristics. Removal efficiencies for measured constituents appear to increase slightly with increasing alum dose. In general, removal efficiencies achieved using alum are substantially greater than those achieved using settling alone.

Table 9.1 Typical removal efficiencies for alum treated stormwater runoff.

\begin{tabular}{lcccc}
\hline \multirow{2}{*}{ Parameter } & $\begin{array}{c}\text { Settled } \\
\text { without } \\
\text { alum }\end{array}$ & \multicolumn{3}{c}{ Alum Dose (mg/l as Al) } \\
\cline { 3 - 5 } & 20 & $5 \mathrm{mg} / \mathrm{l}$ & $7.5 \mathrm{mg} / \mathrm{l}$ & $10 \mathrm{mg} / \mathrm{l}$ \\
\hline Diss. Organic N & 67 & 51 & 62 & 65 \\
Particulate N & 49 & 88 & 94 & 96 \\
Total N & 17 & 65 & 71 & 73 \\
Diss. Ortho-P & 71 & 96 & 98 & 98 \\
Particulate P & 45 & 82 & 94 & 95 \\
Total P & 92 & 86 & 94 & 96 \\
Turbidity & 80 & 98 & 99 & 99 \\
TSS & 44 & 65 & 97 & 98 \\
BOD & 37 & 80 & 63 & 64 \\
Total Coliform & 61 & 96 & 94 & 99 \\
Fecal Coliform & & & 99 & 99 \\
\hline
\end{tabular}

Removal of total phosphorus in alum treated stormwater occurs by direct precipitation of orthophosphorus as aluminum phosphate $\left(\mathrm{AlPO}_{4}\right)$, as well as enmeshment of particulate phosphorus by incorporation into $\mathrm{Al}(\mathrm{OH})_{3}$ floc. Removal of nitrogen species occurs primarily as a result of precipitation of particulate nitrogen and dissolved organic nitrogen, since alum treatment generally does not affect measured concentrations of ammonia or nitrate.

\subsection{System Configuration}

In a typical alum stormwater treatment system, alum is injected into the stormwater flow on a flow-proportioned basis so that the same dose of alum is added to the stormwater flow regardless of the stormsewer discharge rate. A variable speed chemical metering pump is typically used as the injection pump. If the initial laboratory testing indicates that the addition of alum to the target runoff flow will reduce $\mathrm{pH}$ levels to undesirable levels, a buffering agent, such as sodium aluminate $\left(\mathrm{Na}_{2} \mathrm{Al}_{2} \mathrm{O}_{4}\right)$ or sodium hydroxide $(\mathrm{NaOH})$ can be injected along with the alum to maintain desired $\mathrm{pH}$ levels. A separate metering system 
and storage tank will be necessary for the buffering agent. The operation of each injection pump is regulated by a flow meter device attached to each incoming stormwater line to be treated. Measured flow from each stormwater flow meter is transformed into a 4-20 mA electronic signal which instructs the metering pump to inject alum according to the measured flow of runoff discharging through each individual stormsewer line. Mixing of the alum and stormwater occurs as a result of turbulence in the stormsewer line. If sufficient turbulence is not available within the stormsewer line, artificial turbulence can be generated using aeration or physical stormsewer modifications. Since alum addition is regulated by the rate of flow in the stormsewer line, the treatment system is capable of treating stormwater as well as dry weather baseflow.

A series of rate experiments were conducted by Harper (1990) to evaluate the time required for dissolution of alum floc. Since $\mathrm{Al}^{+3} \mathrm{can}$ be a potentially toxic species, floc formation should be complete prior to discharging the treated stormwater into the receiving waterbody. It was determined that floc formation is complete, although on a microscopic scale, and $\mathrm{Al}^{+3}$ is virtually removed from the water column in 45-60 seconds after alum addition. Therefore, alum injection locations are carefully selected to allow a minimum of 45-60 seconds of travel time in the stormsewer line after alum addition prior to reaching the receiving waterbody. The potential toxicity of alum treated runoff was also evaluated by Harper (1990) using standard Fathead Minnow Larval Survival and Growth Tests. Survival percentages for alum treated stormwater at $\mathrm{pH}$ values ranging from 5.5 to 6.5 are similar to that obtained within the control, with a final survival in excess of $95 \%$. Mortalities began to be observed in stormwater runoff treated at a $\mathrm{pH}$ level of 7.0 , with an ultimate survival percentage of approximately $57 \%$ at the end of seven days. However, even though mortalities were observed at a $\mathrm{pH}$ of 7.0 , these mortalities were less than that observed within the raw stormwater which exhibited a survival of only $20 \%$ at the end of the 7-day test period. The rate of mortality in stormwater treated with alum at a $\mathrm{pH}$ of 7.5 was similar to that observed in raw stormwater.

Mechanical components for the alum stormwater treatment system, including chemical metering pumps, stormsewer flow meters and electronic controls, are typically housed in a central facility which can be constructed as an aboveground or below-ground structure. A 2500-6000 gallon (9500-23000 liter) fiberglass storage tank is typically used for bulk alum storage. Alum feed lines and electrical conduits are run from the central facility to each point of alum addition and flow measurement. Alum injection points can be located as far as $3000 \mathrm{ft}(915 \mathrm{~m})$ or more from the central pumping facility. Early designs for alum stormwater treatment systems utilized individual chemical metering pumps and stormsewer flow meters for each point of alum addition. However, in an effort to reduce overall system costs and complexity, current alum stormwater treatment systems often feed alum to multiple points using a single chemical metering pump and control valves. 


\subsection{Water Quality Improvements}

In general, construction and operation of alum stormwater treatment systems have resulted in significant improvements in water quality for treated waterbodies. The degree of observed improvement in water quality is directly related to the percentage of annual hydraulic inputs treated by the alum stormwater treatment system. A comparison of pre-and post-modification water quality characteristics for typical alum stormwater treatment systems, including Lake Ella and Lake Dot (which provide treatment for approximately $95-96 \%$ of the annual hydraulic inputs entering these lake systems), and Lake Osceola (which provides treatment for only $9 \%$ of the annual hydraulic inputs entering this lake system) is given in Table 9.2. Lake Dot is located in Orlando, Florida, and Lake Osceola is located in Winter Park, Florida.

In general, operation of the alum stormwater treatment systems has resulted in a decline in $\mathrm{pH}$ within each of the three waterbodies, with a reduction of approximately 1 unit in Lake Ella and 0.6 units in Lake Osceola. A pH reduction of only 0.1 unit was observed for the Lake Dot treatment system which injects both alum and sodium aluminate, an alkaline form of alum, to control $\mathrm{pH}$ levels within the lake. Significant improvements in dissolved oxygen were also observed in both Lake Ella and Lake Dot. Alum treatment of stormwater runoff resulted in a 78\% reduction in total nitrogen concentrations in Lake Ella, with a $55 \%$ reduction in Lake Dot and a $4 \%$ reduction in Lake Osceola where only a small portion of the annual hydraulic inputs were treated. Most of the total observed nitrogen removal is a result of reducing concentrations of dissolved organic nitrogen and particulate nitrogen since alum is generally ineffective in reducing concentrations of inorganic nitrogen species, such as ammonia or nitrate. Alum stormwater treatment resulted in a substantial reduction in measured concentrations of orthophosphorus and total phosphorus in each of the three lake systems, with total removals of $89 \%, 93 \%$ and $30 \%$ for Lake Ella, Lake Dot and Lake Osceola, respectively. Alum stormwater treatment also reduced inlake concentrations of BOD in each of the three lake systems, with a reduction of $93 \%$ in Lake Ella and $84 \%$ in Lake Dot.

Alum stormwater treatment appears to be extremely effective in reducing primary productivity in receiving waterbodies, as indicated by concentrations of chlorophyll-a, with a reduction of $97 \%$ in Lake Ella, $89 \%$ in Lake Dot and 13\% in Lake Osceola. Reductions in measured concentrations of chlorophyll-a occur as a result of enmeshment and precipitation of algal particles within the water column of the lake by alum floc as well as phosphorus limitation created by low levels of available phosphorus in the water column. Substantial increases in Secchi disk depth were observed in Lake Ella and Lake Dot, and to a lesser extent in Lake Osceola, with improvements of $340 \%$ in Lake Ella, $212 \%$ in Lake Dot 
Table 9.2 Comparison of pre- and post-modification water quality characteristics for typical alum stormwater treatment systems.

\begin{tabular}{|c|c|c|c|c|c|c|c|}
\hline \multirow{2}{*}{ Parameter } & \multirow{2}{*}{ Units } & \multicolumn{2}{|c|}{$\begin{array}{c}\text { Lake Ella } \\
\text { (Tallahassee, FL) }\end{array}$} & \multicolumn{2}{|c|}{$\begin{array}{c}\text { Lake Dot } \\
\text { (Orlando, FL) }\end{array}$} & \multicolumn{2}{|c|}{$\begin{array}{c}\text { Lake Osceola } \\
\text { (Winter Park, FL) }\end{array}$} \\
\hline & & $\begin{array}{l}\text { Before } \\
(1974-85)\end{array}$ & $\begin{array}{c}\text { After } \\
(1 / 88-5 / 90)\end{array}$ & $\begin{array}{l}\text { Before } \\
(1986-88)\end{array}$ & $\begin{array}{c}\text { After } \\
(3 / 89-8 / 91)\end{array}$ & $\begin{array}{c}\text { Before } \\
(6 / 91-6 / 92)\end{array}$ & $\begin{array}{c}\text { After } \\
(2 / 93-12 / 96)\end{array}$ \\
\hline \# of Samples & - & 15 & 11 & 5 & 15 & 12 & 46 \\
\hline $\mathrm{pH}$ & s.u. & 7.41 & 6.43 & 7.27 & 7.17 & 8.22 & 7.63 \\
\hline Diss. $\mathrm{O}_{2}$ (1 minute) & $\mathrm{mg} / \mathrm{I}$ & 3.5 & 7.4 & 6.6 & 8.8 & 8.8 & 8.8 \\
\hline Total N & $\mu \mathrm{g} / \mathrm{l}$ & 1876 & 417 & 1545 & 696 & 892 & 856 \\
\hline Total P & $\mu \mathrm{g} / \mathrm{l}$ & 232 & 26 & 351 & 24 & 37 & 26 \\
\hline BOD & $\mathrm{mg} / \mathrm{l}$ & 41 & 3.0 & 16.8 & 2.7 & 4.4 & 3.4 \\
\hline Chlorophyll-a & $\mathrm{mg} / \mathrm{m}^{3}$ & 180 & 5.1 & 55.8 & 6.3 & 24.8 & 21.7 \\
\hline Secchi Disk Depth & $\mathrm{m}$ & 0.5 & $>2.2$ & $<0.8$ & 2.5 & 1.1 & 1.2 \\
\hline Diss. Al & $\mu \mathrm{g} / \mathrm{l}$ & - & 44 & -- & 65 & 18 & 51 \\
\hline Florida TSI Value & -- & $\begin{array}{c}98 \\
\text { (Hypereutrophic) }\end{array}$ & $\begin{array}{c}47 \\
\text { (Oligotrophic) }\end{array}$ & $\begin{array}{c}86 \\
\text { (Hypereutrophic) }\end{array}$ & $\begin{array}{c}42 \\
\text { (Oligotrophic) }\end{array}$ & $\begin{array}{c}61 \\
\text { (Eutrophic) }\end{array}$ & $\begin{array}{c}56 \\
\text { (Mesotrophic) }\end{array}$ \\
\hline Lake Area & - & \multicolumn{2}{|c|}{$13.3 \mathrm{ac}$} & \multicolumn{2}{|c|}{$5.9 \mathrm{ac}$} & \multicolumn{2}{|c|}{$55.4 \mathrm{ac}$} \\
\hline Watershed Area & -- & \multicolumn{2}{|c|}{$57 \mathrm{ac}$} & \multicolumn{2}{|c|}{$305 \mathrm{ac}$} & \multicolumn{2}{|c|}{$153 \mathrm{ac}$} \\
\hline $\begin{array}{l}\text { Percent of Annual } \\
\text { Hydraulic Inputs Treated }\end{array}$ & $\%$ & \multicolumn{2}{|c|}{95} & \multicolumn{2}{|c|}{96} & \multicolumn{2}{|c|}{9} \\
\hline
\end{tabular}


and 9\% in Lake Osceola. Based upon the Florida TSI Index (Brezonik, 1984), Lake Ella and Lake Dot have been converted from hypereutrophic to oligotrophic status, with a conversion from eutrophic to mesotrophic in Lake Osceola.

A graphical history of total phosphorus concentrations in Lake Lucerne (located in Orlando, FL), which was retrofitted with an alum stormwater treatment system in June 1993 that provides treatment for approximately $82 \%$ of the annual runoff inputs into the lake, is given in Figure 9.1. Prior to construction of the alum stormwater treatment system, total phosphorus concentrations in Lake Lucerne fluctuated widely, with a mean concentration of approximately $100 \mathrm{mg} / \mathrm{l}$. Following star-up of the alum treatment system, total phosphorus concentrations began to decline steadily, reaching equilibrium concentrations of approximately $20-40 \mathrm{mg} / \mathrm{l}$. A slight increase in total phosphorus concentrations is observed during the last half of 1995 when the system was off-line due to lightning damage. When system operation resumed in June 1996, total phosphorus concentrations returned to equilibrium values of approximately $20 \mathrm{mg} / \mathrm{l}$. Mean residence time in Lake Lucerne is approximately 105 days.

In general, measured concentrations of heavy metals have been extremely low in all waterbodies retrofitted with alum stormwater treatment systems, with no violations of heavy metal standards observed in any of these lake systems. Measured levels of dissolved aluminum have also remained low in each lake system. Mean dissolved aluminum concentrations for Lake Ella, Lake Dot and Lake Osceola have averaged $44 \mathrm{mg} / \mathrm{l}, 65 \mathrm{mg} / \mathrm{l}$ and $51 \mathrm{mg} / \mathrm{l}$, respectively. Although there is no standard for dissolved aluminum in the State of Florida, the U.S. EPA has recommended a long-term average of $87 \mathrm{mg} / \mathrm{l}$ for protection of all

\section{LAKE LUCERNE}

Total Phosphorus

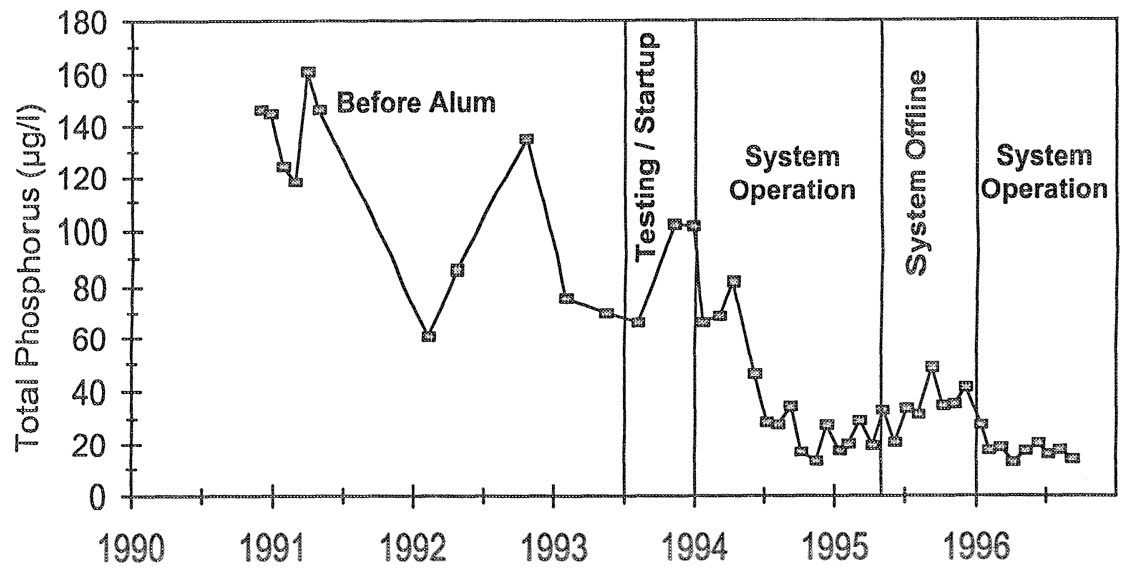

Figure 9.1 Trends in total phosphorus concentrations in Lake Lucerne, before and after alum treatment of stormwater runoff. 
species present in the U.S. The solubility of dissolved aluminum is regulated almost exclusively by $\mathrm{pH}$. As long as the $\mathrm{pH}$ of the treated water can be maintained in the range of 6.0-7.5 during the treatment process, dissolved aluminum concentrations will remain at minimal levels.

\subsection{Floc Accumulation}

Laboratory investigations have been conducted on stormwater runoff collected from a wide range of land uses typical of urban areas to quantify the amount of alum floc generated as a result of alum treatment of stormwater runoff at various treatment doses. After initial formation, alum floc appears to consolidate rapidly for a period of approximately 6-8 days, consolidating to approximately $20 \%$ of the initial floc volume. Additional consolidation appears to occur over a settling period of approximately 30 days, after which collected sludge volumes appear to approach maximum consolidation (Harper, 1990).

Estimates of maximum anticipated sludge production, based upon literally hundreds of laboratory tests involving coagulation of stormwater runoff with alum at various doses, and based upon a consolidation period of approximately 30 days, is given in Table 9.3. At alum doses typically used for treatment of stormwater runoff, ranging from $5-10 \mathrm{mg} \mathrm{Al} /$ liter, sludge production is equivalent to approximately $0.16-0.28 \%$ of the treated runoff flow. Sludge production values listed in Table 9.3 reflect the combined volume generated by alum floc as well as solids originating from the stormwater sample.

Field investigations have also been performed in lake systems receiving alum treated stormwater runoff to document the accumulation rate of alum floc within the sediments of the lake by collection and visual inspection of sediment core samples collected in clear acrylic tubes at selected monitoring sites in each lake. A comparison of observed and predicted floc accumulation rates in lake systems receiving stormwater treatment is given in Table 9.4. Each of the listed lakes has been receiving alum treatment for approximately five years or more.

Table 9.3 Anticipated production of alum sludge from alum treatment of stormwater at various doses after a 30 -day consolidation period.

\begin{tabular}{cccc}
\hline $\begin{array}{c}\text { Alum Dose } \\
(\mathrm{mg} / \mathrm{l} \text { as Al) }\end{array}$ & $\begin{array}{c}\text { As Percent of } \\
\text { Treated Flow }\end{array}$ & $\begin{array}{c}\text { Sludge Production } \\
\text { Per } 1000 \mathrm{~m}^{3} \\
\text { Treated }\end{array}$ & $\begin{array}{c}\text { Per } 10^{6} \text { Gallons } \\
\text { Treated }\end{array}$ \\
\hline 5 & 0.16 & $1.6 \mathrm{~m}^{3}$ & $214 \mathrm{ft}^{3}$ \\
7.5 & 0.20 & $2.0 \mathrm{~m}^{3}$ & $268 \mathrm{ft}^{3}$ \\
10 & 0.28 & $2.8 \mathrm{~m}^{3}$ & $374 \mathrm{ft}^{3}$ \\
\hline
\end{tabular}


Table 9.4 Comparison of observed and predicted floc accumulation rates in lake systems with alum stormwater treatment.

\begin{tabular}{cccc}
\hline Lake & $\begin{array}{c}\text { Predicted } \\
\text { Settling Area }\end{array}$ & $\begin{array}{c}\text { Predicted } \\
\text { Accumulation Rate } \\
(\mathrm{cm} / \mathrm{yr})\end{array}$ & $\begin{array}{c}\text { Observed } \\
\text { Accumulation Rate }\end{array}$ \\
\hline Lake Ella & $50 \%$ of lake bottom & $1 \mathrm{~cm} / \mathrm{yr}$ & $0.33 \mathrm{~cm} / \mathrm{yr}$ \\
Lake Lucerne & areas 10 ft or deeper & $3.3 \mathrm{~cm} / \mathrm{yr}$ & none \\
Lake Osceola & $50 \%$ of lake bottom & $0.5 \mathrm{~cm} / \mathrm{yr}$ & none \\
\hline
\end{tabular}

The primary predicted settling area for floc accumulation was determined by evaluating lake bottom topography and stormsewer inflow characteristics. Predicted floc accumulation rates are based upon the anticipated floc production rates summarized in Table 9.3.

Annual floc production in Lake Ella was predicted to be approximately $10 \mathrm{~mm} / \mathrm{yr}$ over $50 \%$ of the lake bottom. However, floc accumulation evaluations performed in 1990 indicate an observed accumulation rate of approximately $3.3 \mathrm{~mm} / \mathrm{yr}$, approximately one-third of the predicted accumulation rate. The reduced observed accumulation rate is thought to be a result of additional floc consolidation over time and incorporation of the alum floc into the existing sediments. The observed post-treatment floc accumulation rate in Lake Ella is similar to the pre-treatment sediment accumulation rate in Lake Ella resulting from the extremely high algal production prior to the lake restoration efforts in 1985. Sediment accumulation in Lake Lucerne is anticipated to occur in areas $10 \mathrm{ft}(3 \mathrm{~m})$ or deeper, with a predicted accumulation of $33 \mathrm{~mm} / \mathrm{yr}$. However, no sediment accumulation was observed at any of the ten fixed monitoring locations within the lake which have been monitored on approximately an annual basis since start-up of the alum treatment system. A similar conclusion has been reached in Lake Osceola which has no visible floc accumulation after approximately five years of alum stormwater treatment. Both Lake Lucerne and Lake Osceola appear to be incorporating alum floc into the existing sediments with no visible surface floc layer.

\subsection{Sediment Stability}

A large amount of research has been conducted to evaluate the stability of phosphorus and heavy metals in sediments receiving alum floc. These evaluations have been performed using a variety of methodologies, including sediment phosphorus speciation, incubation experiments, and analysis of sediment pore water characteristics. 
Fractionation of inorganic sediment phosphorus has been performed on both pre- and post-alum treatment sediment samples for Lake Ella, Lake Dot, Lake Lucerne and Lake Cannon (in Winter Haven, FL), as well as Lake Davis and Lake Conine, which received whole-lake alum treatments for sediment inactivation. The modified Chang and Jackson (1957) procedure was used for each speciation procedure which divides phosphorus associations into saloid, defined as soluble plus easily exchangeable phosphorus, iron phosphate and aluminum phosphate. Phosphorus associations with saloid and iron phosphate are generally considered to be potentially available within the sediments for recycle back into the water column, particularly under a reduced environment. Sediment associations with aluminum are typically considered to be inert and stable under a wide range of $\mathrm{pH}$ and redox conditions.

In all lake systems where phosphorus fractionation has been evaluated, the introduction of alum floc into the sediments has resulted in a reduction in both saloid and iron-bound associations and an increase in aluminum-bound associations, indicating that phosphorus sediment associations have become more stable following introduction of alum floc. As an example, a comparison of pre- and post-treatment phosphorus fractions in Lake Ella is presented graphically in Figure 9.2. This figure presents post-treatment phosphorus associations as a fraction of pre-treatment concentrations for soluble, iron and aluminum associations. This figure represents the results of sediment cores collected in Lake Ella after approximately 2.5 years of treatment system operation.

Overall, soluble phosphorus has been reduced to only $60 \%$ of that found in the pre-treatment sediments. Phosphorus associations with iron in post-treatment sediments have been reduced to approximately $30 \%$ of that found prior to alum treatment. The sediment profile for iron-bound phosphorus presented in Figure 9.2

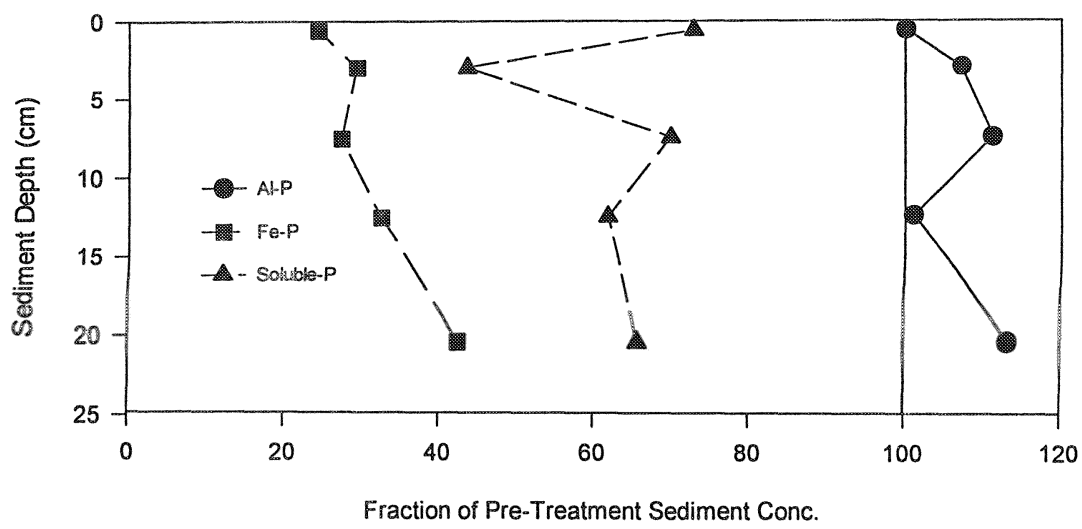

Figure 9.2 Comparison of pre- and post-alum treatment phosphorus fractionation in Lake Ella. 
suggests that the effects of aluminum floc within the sediments has altered sediment phosphorus associations as deep as $150-250 \mathrm{~mm}$ within the sediment, although changes in sediment fractions are most apparent in the top $100 \mathrm{~mm}$ of the sediments.

In contrast, phosphorus associations with aluminum increased in alumtreated sediments by $7 \%$ in the $10-50 \mathrm{~mm}$ layer, $12 \%$ in the $50-100 \mathrm{~mm}$ layer, $4 \%$ in the $100-150 \mathrm{~mm}$ layer, and $14 \%$ in the $150-250 \mathrm{~mm}$ layer. The observed reductions in both saloid and iron-bound associations, combined with the increase in aluminum phosphorus associations, suggests that phosphorus in posttreatment sediments is substantially more stable than phosphorus in pre-treatment sediments. Since aluminum phosphorus associations are virtually immune to changes in redox potential and $\mathrm{pH}$, which can cause iron phosphorus associations to break apart with a subsequent release of phosphorus in soluble forms, the conversion to aluminum phosphate forms indicates that the probability of phosphorus being released from post-treatment sediments is substantially reduced compared with pre-treatment sediments.

After 2.5 years of alum treatment system operation, changes in physical and chemical characteristics of Lake Ella sediments have been limited primarily to the top $10 \mathrm{~mm}$ layer. Moisture content in the $0-10 \mathrm{~mm}$ layer has increased from $62.9 \%$ (pre) to $78.8 \%$ (post), organic content has increased from $15.6 \%$ (pre) to $21.8 \%$ (post), total phosphorus has increased from $1359 \mathrm{mg} / \mathrm{g}$ dry weight (pre) to $1488 \mathrm{mg} / \mathrm{g}$ dry weight (post), and $\mathrm{pH}$ has decreased from 6.02 (pre) to 5.97 (post). Physical-chemical characteristics of sediment layers deeper than $10 \mathrm{~mm}$ are virtually identical under pre- and post-conditions.

Laboratory experiments have also been conducted on sediment samples collected from Lake Ella, Lake Dot, Lake Lucerne and Lake Davis to evaluate the influence of $\mathrm{pH}$ and redox potential on the stability of heavy metals in alum treated sediments. An incubation apparatus was constructed which allows a circulating sediment slurry to be maintained under precise controlled conditions of $\mathrm{pH}$ and redox potential. Samples can then be collected from the sediment slurry to evaluate the solubility of heavy metals within the sediments under various $\mathrm{pH}$ and redox conditions. Experiments were conducted at selected $\mathrm{pH}$ levels typical of values within the sediments of each lake, as well as redox potentials from highly reduced to highly oxidized.

The results of incubation experiments conducted on pre- and post-sediment samples collected from Lake Ella for chromium, copper, lead and zinc are given in Figure 9.3 (Harper, 1990). Sediment metal release was found to be substantially less in alum treated samples than observed in pre-treatment samples collected from the lake under a wide range of $\mathrm{pH}$ conditions and under redox potentials ranging from highly oxidized to highly reduced. Alum floc is capable of tightly binding heavy metals within the sediments, substantially reducing the potential toxicity of in-place sediments. Similar results were obtained for copper, nickel and lead. As alum floc ages, the freshly precipitated $\mathrm{AlOH}_{3}$ forms into a 

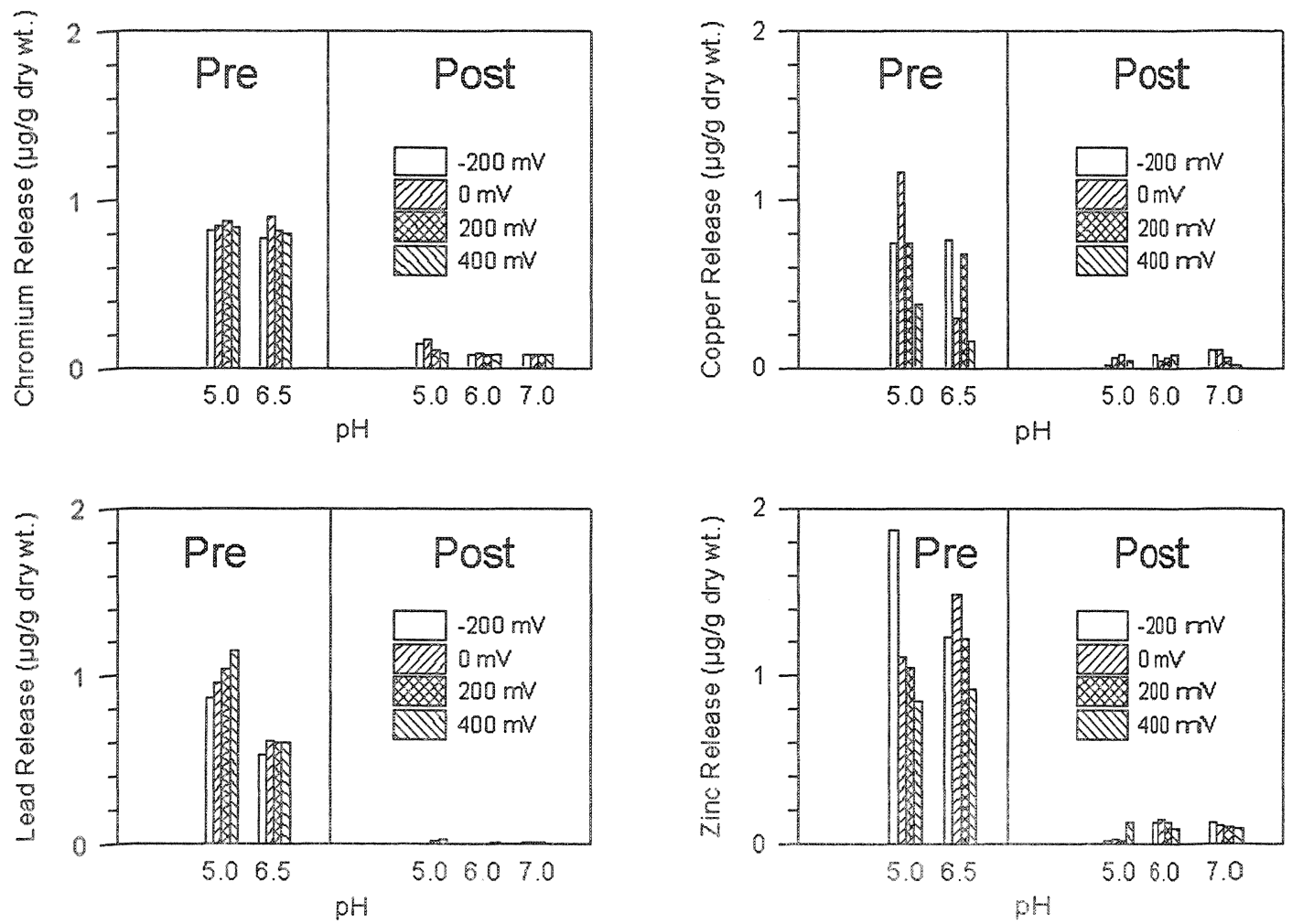

Figure 9.3 Comparison of sediment-metal phase in pre- and post-treatment sediments in Lalk Ella. 
series of ringed structures which are extremely stable and which tightly bind phosphorus and heavy metals in a crystalline lattice network. These phosphorus and metal associations, once combined with alum, are apparently inert to changes in $\mathrm{pH}$ and redox potential normally observed in a natural lake system.

The impact of alum floc on lake sediments has also been evaluated by comparison of pre- and post-treatment sediment pore water concentrations in Lake Ella, Lake Lucerne and Lake Cannon, as well as Lake Davis and Lake Conine which have received one-time whole-lake alum applications. A comparison of sediment pore water concentrations in Lake Lucerne before and after stormwater treatment is given in Table 9.5. Post-treatment samples reflect approximately four years of operation of the alum stormwater treatment system. Introduction of alum floc into the lake sediments has significantly reduced measured concentrations of total nitrogen, total phosphorus and each of the listed heavy metals. Pore water concentrations of total aluminum have also been reduced as a result of replacing pre-treatment aluminum associations with stable $\mathrm{Al}(\mathrm{OH})_{3}$ associations. The reduced pore water concentrations indicated in Table 9.5 provide an enhanced environment for sediment-dwelling organisms.

Table 9.5 Comparison of sediment pore water concentrations in Lake Lucerne before and after alum stormwater treatment.

\begin{tabular}{ccccc}
\hline Parameter & Units & $\begin{array}{c}\text { Pre-Treatment } \\
\text { Samples } \\
(12 / 92)\end{array}$ & $\begin{array}{c}\text { Post-Treatment } \\
\text { Samples } \\
(5 / 97)\end{array}$ & $\begin{array}{c}\text { Percent } \\
\text { Reduction }\end{array}$ \\
\hline Total $\mathrm{N}$ & $\mu \mathrm{g} / \mathrm{l}$ & 9978 & 5846 & 41 \\
Total $\mathrm{P}$ & $\mu \mathrm{g} / \mathrm{l}$ & 531 & 189 & 64 \\
Total $\mathrm{Al}$ & $\mu \mathrm{g} / \mathrm{l}$ & 417 & 123 & 70 \\
Total $\mathrm{Cu}$ & $\mu \mathrm{g} / \mathrm{l}$ & 21 & 6 & 71 \\
Total $\mathrm{Fe}$ & $\mu \mathrm{g} / \mathrm{l}$ & 1389 & 50 & 96 \\
Total $\mathrm{Ni}$ & $\mu \mathrm{g} / \mathrm{l}$ & 17 & 8 & 53 \\
Total $\mathrm{Mn}$ & $\mu \mathrm{g} / \mathrm{l}$ & 314 & 36 & 89 \\
Total $\mathrm{Zn}$ & $\mu \mathrm{g} / \mathrm{l}$ & 80 & 12 & 85 \\
\hline
\end{tabular}

\subsection{Benthic Impacts}

Monitoring of benthic macroinvertebrates has been conducted on an annual basis in many of the lake systems currently receiving alum stormwater treatment. Based upon this available data, long-term trends in benthic macroinvertebrate populations are now becoming apparent. A comparison of benthic surveys conducted in Lake Ella from 1985-1990 is summarized in Table 9.6. Immediately 
Table 9.6 Comparison of benthic surveys conducted in Lake Ella from 1985-1990.

\begin{tabular}{ccccc}
\hline \multirow{2}{*}{ Date } & Lake Condition & \multicolumn{3}{c}{ Average Number of Organisms $/ \mathrm{m}^{2}$} \\
& Limnodrilus sp. & Leeches & Total \\
\hline $11 / 29 / 85$ & $\begin{array}{c}\text { Immediately prior } \\
\text { to lake drawdown }\end{array}$ & 0 & 0 & 0 \\
$1 / 16 / 87$ & $\begin{array}{c}\text { Following dredging, after lake } \\
\text { had refilled for 3-4 months } \\
\text { After 2.5 years of } \\
\text { alum system operation }\end{array}$ & 0 & 0 & 0 \\
\hline
\end{tabular}

prior to drawdown of the lake for construction and sediment removal purposes, no benthic organisms were found at any of the six monitoring sites conducted within the lake. Following the dredging and refilling process in January 1987, no benthic organisms were again found at any of the six monitoring locations. However, after approximately 2.5 years of alum system operation, it appears that benthic macroinvertebrates are beginning to recolonize the sediments of Lake Ella. This recolonization may be in response to improved water quality and reduced toxicity within the sediments as a result of incorporation of heavy metals and other toxic compounds into stable associations with alum floc.

Benthic macroinvertebrate monitoring has also been conducted in Lake Lucerne on approximately an annual basis since 1994. Organism density has decreased from 9495 organisms $/ \mathrm{m}^{2}$ in pre-treatment samples collected in November 1992 to a density of 539 organisms $/ \mathrm{m}^{2}$ in post-treatment samples collected in January 1997. This $94 \%$ reduction in organism density closely follows the observed reduction in system productivity resulting from introduction of the alum stormwater treatment system. The reduction in organism density has been accompanied by a dramatic shift from a community dominated primarily by detritivores to a benthic community composed primarily of carnivores. Post-treatment samples collected in 1995 and 1997 included members of Ephemeroptera (mayflies), Ceratopogonidae (no see-ums), Chaoboridae (phantom midges) and Planorbidae (orb snails), which are generally indicative of relatively clean environments, and were absent in pre-treatment communities. In addition, no deformities were noted in post-treatment organisms collected during 1995 and 1997, while a large number of deformities were observed in pretreatment benthic communities collected in 1992. Sediment composition in Lake Lucerne ranges from dark organic muck to brown fine sand.

A comparison of pre- and post-treatment benthic monitoring in Lake Osceola is given in Table 9.7. The alum treatment system for Lake Osceola provides treatment for approximately $9 \%$ of the annual hydraulic inputs into the lake. Post-treatment samples appear to have increased slightly in terms of population density and mean taxa richness, while decreasing slightly in mean sample diversity and mean sample evenness. 
Table 9.7 Comparison of pre- and post-treatment benthic macroinvertebrate surveys in Lake Osceola.

\begin{tabular}{ccc}
\hline Parameter & $\begin{array}{c}\text { Pre-Treatment } \\
\text { Monitoring } \\
(10 / 92)\end{array}$ & $\begin{array}{c}\text { Post-Treatment } \\
\text { Monitoring }^{1} \\
(12 / 95)\end{array}$ \\
\hline Total Organisms (organisms $\left./ \mathrm{m}^{2}\right)$ & 5093 & 5153 \\
Mean Taxa Richness & 8.0 & 8.5 \\
Mean Sample Diversity & 1.51 & 1.23 \\
Mean Sample Evenness & 0.49 & 0.43 \\
$\mathrm{n}=12$ samples & &
\end{tabular}

\subsection{Construction and O\&M Costs}

A summary of construction and annual operation and maintenance (O\&M) costs for existing alum stormwater treatment facilities, with treated watershed areas ranging from $64 \mathrm{ac}$ to $1450 \mathrm{ac}$, is given in Table 9.8. Construction costs for alum stormwater treatment systems have ranged from $\$ 75,000$ to $\$ 400,000$, depending upon the number of outfalls to be retrofitted. In general, the capital cost of constructing alum stormwater treatment systems is independent of the watershed size since the capital cost for constructing a treatment system for a 100 ac watershed at one location is identical to the cost of constructing a system to treat $1000 \mathrm{ac}$ at the same location, although annual O\&M costs would increase. The average capital cost for existing alum stormwater treatment facilities is $\$ 245,998$ $(\$ 1,542 /$ acre, or $\$ 627 / \mathrm{ha}$, treated).

Estimated O\&M costs are also provided in Table 9.8 and include chemical, power, manpower for routine inspections, and equipment renewal and replacement costs. Operation and maintenance costs for existing alum stormwater treatment systems range from $\$ 5,500$ to $\$ 26,298$ per year ( $\$ 27$ to $\$ 208$ /acre treated/year, or $\$ 11$ to $\$ 85 /$ ha treated/year).

\subsection{Comparison with Other Stormwater Treatment Alternatives}

In general, removal efficiencies obtained with alum stormwater treatment are superior to removal efficiencies obtained using a dry retention $(0.5 \mathrm{inch}[13 \mathrm{~mm}])$ or wet detention stormwater management facility. A comparison of treatment efficiencies for common stormwater management systems is given in Table 9.9 (Harper, 1995). Estimated removal efficiencies for alum treatment exceed removal efficiencies achieved in dry retention for total phosphorus and TSS, but 
Table 9.8 Summary of construction and O\&M costs for existing alum stormwater treatment facilities.

\begin{tabular}{|c|c|c|c|c|c|}
\hline Project & $\begin{array}{l}\text { Area } \\
\text { Treated } \\
\text { (ac) }\end{array}$ & $\begin{array}{l}\text { Construction } \\
\text { Cost per } \\
\text { System } \\
(\$)\end{array}$ & $\begin{array}{c}\text { Estimated } \\
\text { Annual } \\
\text { O\&M } \\
\text { Cost } \\
(\$)\end{array}$ & $\begin{array}{c}\text { Construction } \\
\text { Cost } \\
\text { per Area } \\
\text { Treated } \\
\text { (\$/ac) }\end{array}$ & $\begin{array}{c}\text { Annual } \\
\text { O\&M } \\
\text { Cost } \\
\text { per Area } \\
\text { Treated } \\
(\$ / a c)\end{array}$ \\
\hline Lake Ella & 158 & 200,400 & -- & 1,268 & -- \\
\hline Lake Dot & 305 & 250,000 & - & 823 & $\ldots$ \\
\hline Lake Lucerne & 272 & 400,000 & 16,000 & 1,472 & 59 \\
\hline Lake Osceola & 153 & 300,000 & 6,500 & 1,959 & 43 \\
\hline Lake Cannon & 490 & 135,000 & 13,100 & 276 & 27 \\
\hline Channel 2 & 84 & 180,000 & 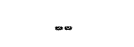 & 2,144 & $\ldots$ \\
\hline $\begin{array}{l}\text { Lake Virginia } \\
\text { North }\end{array}$ & 64 & 242,000 & - & 3,769 & $\ldots$ \\
\hline Celebration & 158 & 300,000 & 25,000 & 1,898 & 158 \\
\hline Lake Holden & 183 & 292,000 & $\ldots$ & 1,598 & $\ldots$ \\
\hline Lake Tuskawilla & 311 & 242,000 & 19,627 & 777 & 63 \\
\hline Lake Rowena & 538 & 75,000 & -- & 139 & - \\
\hline Lake Mizell & 74 & 300,000 & 15,389 & 4,049 & 208 \\
\hline Lake Maggiore (5) & 1450 & 400,000 & 21,450 & 1,379 & 74 \\
\hline Webster Avenue & 91 & 130,000 & 12,397 & 1,423 & 136 \\
\hline $\begin{array}{l}\text { Lake Virginia } \\
\text { South }\end{array}$ & 437 & 288,000 & $\cdots$ & 659 & - \\
\hline Merritt Ridge & 195 & 201,575 & 26,298 & 1,033 & 135 \\
\hline Averages & 310 & $\$ 245,998$ & $\$ 17,307$ & $\$ 1,542$ & $\$ 100$ \\
\hline
\end{tabular}

removal efficiencies for total nitrogen and BOD appear to be slightly lower than those achieved in dry retention. In general, dry retention, which percolates most of the runoff into groundwater, is considered to be the most effective common stormwater management technique in use today. Removal efficiencies achieved with alum treatment appear to exceed removal efficiencies which can be obtained using wet detention, wet detention with filtration, dry detention, or dry detention with filtration.

Alum treatment of stormwater runoff also compares favorably with other stormwater treatment alternatives with respect to both initial capital construction costs and annual O\&M costs. A comparison of costs for alum stormwater treatment and equivalent retention facilities is given in Table 9.10. Initial capital construction costs and annual O\&M costs for three existing alum stormwater treatment facilities are compared with the estimated cost for construction of an equivalent retention facility for treatment of the first $0.5 \mathrm{inch}(13 \mathrm{~mm})$ of runoff. Each of the equivalent retention facilities would require purchase of land in heavily urbanized areas which, if available at all, would be prohibitively expensive. The cost listed for the equivalent retention facilities include land costs 
Table 9.9 Comparison of treatment efficiencies for common stormwater management systems.

\begin{tabular}{ccccc}
\hline \multirow{2}{*}{ Type of System } & \multicolumn{4}{c}{ Estimated Removal Efficiencies (\%) } \\
\cline { 2 - 5 } & Total N & Total P & TSS & BOD \\
\hline Dry Retention (0.50-inch) & 80 & 80 & 80 & 80 \\
Wet Detention & $20-30$ & $60-70$ & 85 & $50-60$ \\
Wet Detention with Filtration & 0 & 60 & $>90$ & 90 \\
Dry Detention & $10-20$ & $20-40$ & $60-80$ & $30-50$ \\
Dry Detention with Filtration & $0-20$ & $0-20$ & $60-90$ & $0-55$ \\
Alum Treatment & $50-70$ & $>90$ & $>95$ & 60 \\
\hline
\end{tabular}

Table 9.10 Comparison of costs for alum stormwater treatment and equivalent retention facilities.

\begin{tabular}{|c|c|c|c|c|c|c|}
\hline \multirow[b]{2}{*}{ Location } & \multirow[b]{2}{*}{$\begin{array}{c}\text { Area } \\
\text { Treated } \\
\text { (ac) }\end{array}$} & \multicolumn{2}{|c|}{$\begin{array}{c}\text { Alum Treatment } \\
\text { System }\end{array}$} & \multicolumn{3}{|c|}{ Equivalent Retention Facility } \\
\hline & & $\begin{array}{c}\text { Capital } \\
\text { Costs } \\
(\$)\end{array}$ & $\begin{array}{c}\text { Annual } \\
\text { O\&M } \\
\text { Costs } \\
(\$)\end{array}$ & $\begin{array}{c}\text { Land } \\
\text { Area } \\
\text { Required }^{2} \\
\text { (ac) }\end{array}$ & $\begin{array}{l}\text { Land } \\
\text { Cost } \\
(\$)\end{array}$ & $\begin{array}{c}\text { Annual } \\
\text { O\&M } \\
\text { Costs } \\
(\$)\end{array}$ \\
\hline Lake Osceola & 88 & 235,000 & 6,500 & 3.0 & $1,500,000^{4}$ & 9,000 \\
\hline Lake Lucerne & 210 & 420,000 & 16,000 & 7.3 & $3,700,000^{4}$ & 21,900 \\
\hline Lake Cannon & 490 & 135,000 & 13,100 & 17.0 & $850,000^{5}$ & 51,000 \\
\hline
\end{tabular}

only and do not include construction costs. Estimated annual O\&M cost for retention pond maintenance, such as routine mowing, weed control and trash removal, is higher than the estimated O\&M costs for the alum treatment systems which includes chemicals, weekly inspections, and parts and supplies.

\subsection{Floc Collection and Disposal}

Although virtually all existing alum stormwater treatment systems allow for floc settling directly in receiving waterbodies, and only beneficial aspects of alum floc accumulation have been observed to date, current alum treatment system designs emphasize collection and disposal of floc rather than allowing floc accumulation 
within surface water systems. Several innovative designs have been developed for collection and disposal of alum floc. Where possible, sump areas have been constructed to provide a basin for collection and accumulation of alum floc. The accumulated floc can then be pumped out of the sump area, using either manual or automatic techniques, on a periodic basis. Several current treatment systems provide for automatic floc disposal into the sanitary sewer system at a slow controlled rate. Since alum floc is virtually inert and has a consistency similar to that of water, acceptance of alum floc on a periodic basis poses no operational problem for wastewater treatment facilities. A schematic of a settling pond designed for the Lake Osceola system is given in Figure 9.4.

A recent design for collection of floc discharging from a submerged pipe in a lake system is also illustrated in Figure 9.4. The floc containment area consists of a fabric mesh with holes sized to allow water flow while trapping floc particles. The floc is then collected in the sump area in the bottom of the containment area and pumped on a periodic basis to the sanitary sewer system or adjacent drying bed. Drying characteristics for alum sludge are similar to a wastewater treatment plant sludge. A drying time of approximately 30 days is sufficient to dewater and dry the sludge, with a corresponding volume reduction of $80-90 \%$. Dried alum sludge has chemical characteristics suitable for general land application.

\subsection{Conclusions}

Alum treatment of stormwater runoff has emerged as a viable and cost-effective alternative for retrofitting stormwater systems in urban areas. Based upon the first 10 years of experience with alum stormwater treatment, the following conclusions have been reached:

1. In lake systems where a large percentage of the annual runoff inputs are retrofitted with an alum treatment system, alum treatment has consistently achieved a $90 \%$ reduction in total phosphorus, $50-70 \%$ reduction in total nitrogen, $50-90 \%$ reduction in heavy metals, and $>99 \%$ reduction in fecal coliforms. However, ultimate water quality improvements in the receiving waterbodies are highly correlated with the percentage of total inputs treated by the system.

2. The observed accumulation rate of alum floc in the sediments of receiving waterbodies appears to be substantially lower than the predicted accumulation rate due to additional floc consolidation over time and incorporation of alum floc into the existing sediment.

3. In all lake systems where phosphorus fractionation has been evaluated, the introduction of alum floc into the sediment has resulted in a reduction in both saloid and iron-bound associations and an 

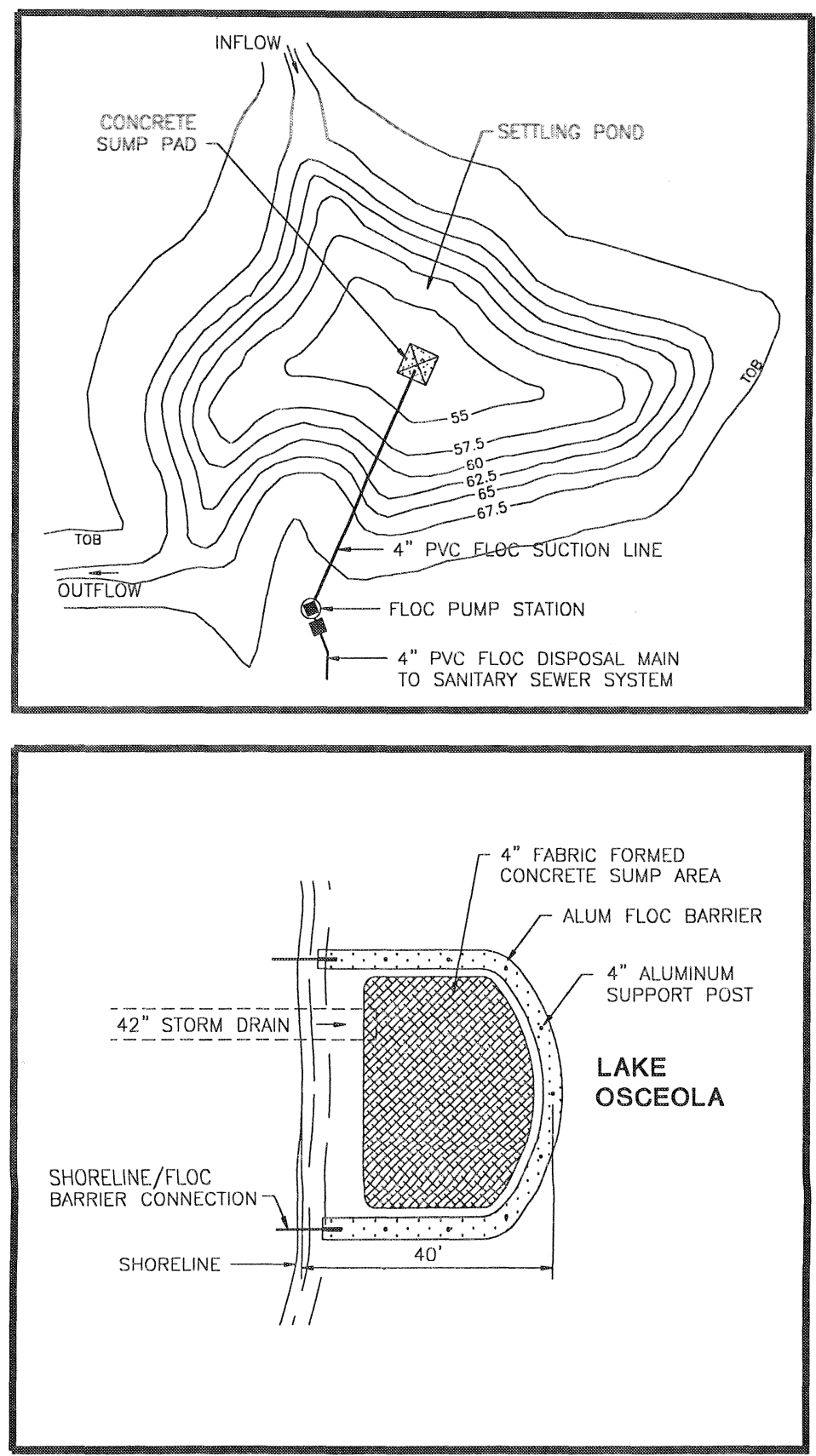

Figure 9.4 Typical schematics of floc collection and disposal systems. 
increase in aluminum-bound associations, indicating that phosphorus sediment associations have become more stable following introduction of alum floc.

4. Sediment metal associations in post-alum treated sediments appear to be substantially more stable under a wide range of $\mathrm{pH}$ conditions and redox potentials than observed in pre-treatment sediment samples. Phosphorus and metal associations, once combined with alum, appear to be virtually inert to changes in $\mathrm{pH}$ and redox potential normally observed in a natural lake system.

5. In all lakes tested, introduction of alum floc into the lake sediments has significantly reduced measured pore water concentrations of total nitrogen, total phosphorus and heavy metals, reducing the potential toxicity of in-place sediments.

6. In general, benthic macroinvertebrate monitoring has indicated a reduction in organism density after initiation of alum stormwater treatment which closely follows the observed reduction in system productivity due to nutrient removals. The reduction in organism density is accompanied by a dramatic shift from a community dominated primarily by detritivores to a benthic community composed primarily of carnivores. Clean water indicator species, which were absent in pre-treatment communities, have begun to colonize many lake systems.

7. Construction costs for alum stormwater treatment systems are largely independent of the watershed area to be treated and depend primarily upon the number of outfalls to be retrofitted.

8. In general, removal efficiencies obtained with alum stormwater treatment are superior to removals obtained using a dry retention or wet detention stormwater management facility.

9. Alum treatment of stormwater runoff is often substantially less expensive than other stormwater treatment alternatives with respect to both initial capital construction costs and annual O\&M costs.

10. Several innovative designs have recently been developed for collection of alum floc in sump areas and containment areas, with floc disposal to sanitary sewer or adjacent drying beds.

\section{References}

Brezonik, P.L. (1984). Trophic State Indices: Rationale for Multivariate Approaches. In Lake and Reservoir Management, pp. 427-430, EPA-440/5-84-001.

Chang, S.C., and Jackson, J.L.(1957). AFractionation of Soil Phosphorus.@ Soi. Sci., 84, 133-144. 
Cooke, G.D., and Kennedy, R.H. (1981). Precipitation and Inactivation of Phosphorus as a Lake Restoration Technique. EPA-600/3-81-012.

Garrison, P.J., and Knauer, D.J. (1984). Long-Term Evaluation of Three Alum Treated Lakes. In Lake and Reservoir Management, pp. 513-517. EPA-440/5-84-001.

Harper, H.H. (December 1990). Long-Term Performance Evaluation of the Alum Stormwater Treatment System at Lake Ella, Florida. Final Report submitted to the Florida Department of Environmental Regulation, Project WM339.

Harper, H.H. (October 1995). Pollutant Removal Efficiencies for Typical Storm-water Management Systems in Florida. In Proceedings of the 4th Biennial Stormwater Research Conference (Sponsored by the Southwest Florida Water Management District), pp. 6-17, Clearwater, FL.

Jernelov, A. (1970). Phosphate Reduction in Lakes by Precipitation with Aluminum Sulfate. $5^{\text {th }}$ International Water Pollution Research Conference. New York: Pergamon Press. 